\title{
Üniversite Çalışanlarının İş Sağlığı ve Güvenliği Eğitimi Konusundaki Bilinç Düzeylerinin Araştırılması
}

\author{
Betül Yenisarı ${ }^{1}$, Burcu Mestav ${ }^{2}$, Ömer Faruk Öztürk ${ }^{1,3^{*}}$ \\ ${ }^{1}$ Çanakkale Onsekiz Mart Üniversitesi, Fen Bilimleri Enstitüsü, İş Güvenliği ABD, Çanakkale \\ ${ }^{2}$ Çanakkale Onsekiz Mart Üniversitesi, Fen Edebiyat Fakültesi, İstatistik Bölümü, Çanakkale \\ ${ }^{3}$ Çanakkale Onsekiz Mart Üniversitesi, Fen Edebiyat Fakültesi, Kimya Bölümü, Çanakkale
}

21.01.2019 Geliş/Received, 27.11.2019 Kabul/Accepted

\section{$\ddot{O} \mathbf{z}$}

İş Sağlığı ve Güvenliği (İSG), çeşitli endüstri ve faaliyetlere özgü olarak tıp, psikoloji, eğitim, toksikoloji, ergonomi, fizik, kimya, ekonomi, hukuk, teknoloji gibi bilimsel alanlarla ilgili konulara temas eden geniş kapsamlı ve çok disiplinli bir kavramdır. İSG, bu çok çeşitli alanlarla ilgili ve ilişkili olmasının yanı sıra, bazı temel ilkelere sahiptir. Bu ilkelerden en önemlisi, her çalışanın İSG haklarına sahip olması ve bu hakların güvence altına alınması gerekliliğidir. Diğer önemli ilke ise işyerinde sağlık ve güvenliğin tesisi için çalışanın, işverenin ve devletin birtakım sorumlulukları ve yükümlülüklerinin olmasıdır. Hak ve sorumlulukların tam olarak yerine getirilmesi için öncelikle bu konuda bilgi sahibi olmak, dolayısıyla eğitim ve öğretim almak gerekmektedir. Bu araştırma çalışmasında, çalışanların İS eğitimi konusundaki bilinç düzeylerini belirlemek amacıyla betimsel bir alan çalışması yapılmıştır. Çalışmada nicel araştırma tekniklerinden kaynak tarama ve anket yöntemleri kullanılmıştır. Anket, Çanakkale Onsekiz Mart Üniversitesi'nin farklı birimlerinde görev yapan akademik ve idari personel ile yüz yüze görüşülerek gerçekleştirilmiştir. Katılımcıların anket formlarına verdikleri cevaplar Cronbach Alpha testi kullanılarak güven analizine tabi tutulmuştur. Çalışma sonucunda, çalışanların farklı demografik (cinsiyet, bölüm, medeni durum, unvan gibi) özelliklerine göre İSG konusundaki bilgi düzeyleri ve farkındalıkları tablolar halinde gösterilmiştir.

Anahtar Kelimeler: iş güvenliği, çalışan hakları, çalışan farkındalığı, üniversite çalışanları, istatiksel analiz

\section{Investigation of the Awareness Levels of University Staff about Occupational Health and Safety Education}

\begin{abstract}
*Sorumlu Yazar (Corresponding Author): Ömer Faruk Öztürk (e-posta: ofozturk@comu.edu.tr)

Bu makale Betül Yenisarı'nın tez konusu kapsamında yazılmıştır
\end{abstract}

Occupational Health and Safety (OHS) is a comprehensive and multidisciplinary concept that touches on topics related to scientific fields such as medicine, psychology, education, toxicology, ergonomics, physics, chemistry, economics, law, technology etc. OHS has some 
basic principles as well as being related to a wide range of fields. The most important of these principles is that each employee must have OHS rights and these rights must be secured. Another important principle is that the employee, employer and the goverment have certain responsibilities and obligations for the establishment of health and safety in the workplace. The fulfillment of rights and responsibilities precisely requires knowledge of this issue and therefore it requires education and training. In this research, a descriptive field study was conducted in order to determine the awareness level of the employees about OHS training.

The resource scanning and survey methods, which are quantitative research techniques were used in the study. The survey was conducted by face to face interviews with academic and administrative staff working at different units of Çanakkale Onsekiz Mart University. The responses to questionnaire forms were subjected to confidence analysis using the Cronbach Alpha test. As a result of the study, the level of knowledge about the OHS based on different demographic characteristics (such as gender, department, marital status, title) of the employees was shown in schedules.

Keywords: occupational safety, employee rights, employee awareness, university staff, statistical analysis

\section{Giriş}

\section{1.İş Sağlığı ve Güvenliği Tanımı}

İş, sağlık ve güvenlik kelimelerinin birleşimi ile oluşmuş olan İş Sağlığı ve Güvenliği (İSG), tarihsel süreç içerisinde ülkelere ve kültürlere göre farklı anlamlara gelmiştir ve gelecektir.

Türk Dil Kurumu'na (TDK) göre iş (işyeri) “bir çalışmanın uygulandığı mekan” ve "çalışanın çalışma akdine göre çalıştığı mekan" anlamlarına gelmektedir. Güvenlik kelimesi ise "Toplumsal yaşamda kamusal düzenin aksamadan sağlanması, bireylerin korkmadan yaşayabilme hali, emniyet" anlamlarına gelmektedir (TDK, 2017). Yine TDK ya göre sağlık kelimesi "Kişinin fiziksel, yaşamsal ve ruhsal yönden tam bir iyilik durumunda olması, beden sağlığı, esenlik, sıhhat, afiyet" anlamlarına gelmektedir. Dünya Sağlık Örgütü (WHO)'ya göre ise sağlık "kişinin fiziksel, zihinsel ve sosyal olarak tam bir iyi hal içinde bulunması, hastalık ve sakatlığın olmaması durumu" olarak tanımlanmıştır (WHO, 2017).

Genel olarak İş Sağlığı ve Güvenliği; çalışma hayatında meydana gelebilecek iş kazalarının ve meslek hastalıklarının oluşmasına sebep olacak tehlike kaynaklarının tespit edilmesini ve bu tehlike kaynaklarının oluşturacağı risklerin analiz edilerek bunların engellenmesi için alınması gereken önlemleri belirleyen, acil durum planlarının hazırlanmasını ve uygulanmasını sağlayan, çalışanların iş sağlı̆̆ belirterek bu konuda devlete, işverene ve çalışana bir takım haklar ve sorumluluklar yükleyen bir sistemdir (Demircioğlu ve Centel, 2003; Özkılıç, 2005; Tanır, 2004; Akyiğit, 2001).

\section{2. İş Sağlığı ve Güvenliğinin Amaç ve Önemi}

İş yaşamı hayatımızda önemli bir yerdedir, çünkü genelde günümüzün sekiz saati iş ortamında geçer. Dolayısıyla, çalışma ortamları güvenli ve sağlıklı olmalıdır. Her geçen gün dünyanın dört bir yanındaki pek çok işçi tehlikeli gazlar, gürültü, titreşim ve aşırı sıcaklıklar gibi sağlığa zararlı risklere maruz kalmaktadır. Mevcut bu risklerin yanı sıra bazı işverenler de çalışanlarının mesleki sağlık ve güvenliğinin korunması konusunda gerçekten endişe 
duymamakta, hatta bu konuda endişe duymaları gerekliliğinin ahlaki ve yasal bir sorumluluk olduğunu bilmemektedirler (Montero ve ark., 2009).

ILO'nun raporuna göre her gün 6300, y1lda 2,4 milyondan fazla kişi mesleki kazalar veya işle ilgili hastalıklar sonucu hayatını kaybetmektedir. Çalışma ortamlarında yılda 317 milyon kaza meydana gelmektedir ve bu kazaların birçoğu işten ayrılmalarla sonuçlanmaktadır. Bu günlük kayıpların insani maliyeti çok fazladır ve yeterli düzeyde olmayan iş sağlığ 1 ve güvenliği önlemlerinin ekonomiye yükü, yıllık bazda Gayri Safi Milli Gelirin yaklaşık \%4'nü kapsadığı düşünülmektedir. İşverenler, yaşanan iş kazaları ve meslek hastalıkları yüzünden nitelikli eleman kaybı, erken yaşta emeklilik ve yüksek meblağlı sigorta primleri ile karşı karşıya kalmaktadirlar (ILO, 2015).

İş yerindeki güvenlik ve sağlığın iyileştirilmesi hem şirketlere hem de toplumlara bir bütün olarak ekonomik yararlar getirebilir. Oluşan iş kazası sonucu çalışan, işveren ve ülke ekonomisi doğrudan veya dolaylı olarak maddi yönden zarar görebilir. Oluşabilecek ekonomik zararın yanı sıra kazalar sonucu kişiler ve toplumlar psikolojik ve sosyal yönden de etkilenebilir. İSG ile işyerinde yaşanan bu olumsuzların birçoğu, önleme, raporlama ve denetleme faaliyetleri ile azaltılabilir veya önlenebilir.

\section{3. İş Sağlığı ve Güvenliğinde Tarafların, Hak, Yükümlülük ve Görevleri}

\subsection{1. Çalışanın Hakları}

İş hayatında; yaşamın ve sağlığın korunması gittikçe daha fazla kabul gören ve en temel çalışan haklarındandır. Bunun yanı sıra çalışanların da kendi güvenliklerini sağlama ve yaptıkları bir hata sonucu diğer çalışanların güvenliğini tehlikeye atmamaya dikkat etmek gibi görevleri vardır.

Çalışanların iş ile ilgili gerekli bilgiye sahip olma, güvenlik veya sağlıkları için herhangi bir tehlike söz konusu olduğunda işi durdurma hakları vardır. Bu hakka sahip olmak ve kendi güvenlik ve sağlığına dikkat etmek için çalışanlar mesleki riskleri ve tehlikeleri anlamalıdırlar. Bu nedenle tehlikelere karşı yeterince bilgilendirilmeli ve görevlerini güvenli bir şekilde yerine getirebilmeleri için yeteri kadar eğitim almaları gerekmektedir.

\subsection{2. İşverenin Yükümlülüğü}

Mesleki riskler işyerinde ortaya çıtığı için, iş ortamının güvenli ve sağlıklı olmasını sağlamak işverenlerin sorumluluğundadır. İşverenler mesleki riskleri önlemeli ve çalışanları korumalıdır. Bununla beraber işverenlerin mesleki tehlikeler hakkında bilgi sahibi olmaları ve İSG'yi sağlamak açısından gerekli tüm önlemleri alması gerekmektedir. Çalışanların İSG konusunda eğitimi, işverenlerin yapması gereken en önemli görevlerdendir. İşçiler, yalnızca işlerini nasıl yapacaklarını değil, aynı zamanda hayatlarını ve sağlığını ve çalışma sırasında meslektaşlarının sağlı̆̆ını nasıl koruyacakları hakkında bilgi sahibi olmalıdır.

\subsubsection{Devletin Görevi}

Hükümetler, İSG politikalarını hazırlamakla ve bunların uygulanmasını sağlamakla sorumludur. Bu konuda devletteki yetkili makam, düzenlemelerin veya uygulama kanunları yayınlanmalı ve periyodik olarak bu kanunları gözden geçirilmelidir. Tehlikeleri tanımlamak ve bunları aşmanın yollarını bulmak için araştırma başlatmalıdır. Yetkililer işverenlere ve 
işçilere bilgi ve tavsiye sağlamalıdır. Ayrıca potansiyel risklerin yüksek olduğu felaketlerden kaçınmak için özel tedbirler almalıdırlar.

\section{4. İş Sağlığı ve Güvenliğinde Eğitim}

Eğitim ve bilgilendirme; insanların sahip olduğu davranışlarını değiştiren, sahip olduğu bilgi düzeyini arttıran, mevcut yeteneklerini geliştirerek düşünce yapısına kaynak sağlayan bir olgudur (Akgemci, 1997; Varış, 1985; Akyüz, 1993; Kale ve Yanık, 2018). Sanayinin gelişmesi, işçilerin işyerlerinde maruz kaldığı iş kazalarının ve meslek hastalıklarının sayısının da artmasına neden olmuştur (Işık, 2000). İşçilerin gerek aldıkları eğitim düzeylerinin gerekse yaptıkları iş ile ilgili eğitim düzeylerinin düşük olması, güvenlik açısından uyulması zorunlu olan talimatlara uymamaları, ISG konusunda yeterli bilince sahip olmamaları ve ayrıca işverenlerin İSG konusuna yeteri kadar önem vermemeleri iş kazaları ve meslek hastalıklarının meydana gelmesine sebep olmaktadır (Alper, 1992). Gelişen teknoloji ile beraber, İSG kavramı çalışma yaşamının tüm alanlarına yayılmıştır. Yeni iş alanları, üretilen kimyasal maddeler, teknolojik makine ve teçhizatlar gibi nedenler güvenlik ve sağlık sorunlarının yaşanmasına ve çalışma alanlarında iş sağlığı ve güvenliği uygulamalarının yürürlüğe konulmasını zorunlu hale getirmiştir. Bunun yansıması olarak da işyerlerinde iş sağlığı ve güvenliği eğitimlerinin önemi net bir şekilde ortaya çıkmıştır. Gerek toplumsal bazda gerekse işyerlerinde, bireylere iş sağlı̆̆ ve güvenliği bilincinin kazandırılması ancak bu eğitimlerle mümkündür. Özellikle işyerlerinde çalışanların işe başladığı tarihten işten ayrıldığı tarihe kadar yaptıkları iş ile ilgili bilgi ve becerilerini artırıcı hizmet içi eğitimlerin sistemli ve sürekli yapılması büyük önem arz etmektedir (Cılga, 2004). Çalıştığı ortamda diğer çalışanlarla iyi ilişki kurabilen, bireysel gereksinimleri dikkate alabilen, karşılaşılan problemleri proaktif yaklaşımla çözebilen, çalışma ortamına uyum sağlayan çalışana duyulan ihtiyaç her geçen gün artmaktadır. Hizmet içi eğitimler bu noktada devreye girerek bu ihtiyacı karşılayacak eğitimlerin verilmesini sağlamaktadır. Hizmet içi eğitimler; işe yeni başlayan personelin işyerine ve yapacağı işe uyum sağlamasına yardımcı olmayı, personelin işyerinin genel çalışma kurallarının en kısa sürede öğretmesini sağlamayı, personelin işyerinin farklı alanlarında eğitimini tamamlama imkanı vermeyi, iş kazaları ve meslek hastalıkları hakkında bilgi vermeyi, personelin özgüvenini artırarak işinde başarılı olmasını sağlamayı amaçlamaktadır (Şerifoğlu ve Kürşat, 2007; Kale ve Yanık, 2018).

\section{Materyal ve Yöntem}

\subsection{Araştırmanın Amacı}

Bu araştırmanın amacı, Çanakkale Onsekiz Mart Üniversitesi'ndeki kamu çalışanlarının İSG alanında farkındalık düzeylerini belirlenmesi ve çalışma ortamında karşılaşılan risklerin ortaya konulmasıdır. 2012 yılında yürürlüğe giren 6331 sayılı İSG kanundaki mevzuatın üniversite çalışanlarına nasıl yansıdığı da çalışmada irdelenmiştir. Ortaya konacak bilgi düzeyi seviyesi ile farkındalığı artırmak için alınması gereken önlemler çalışma sonunda belirtilmiştir.

\subsection{Araştırmada Kullanılan Yöntem}

Bu araştırmada, konu ile ilgili literatür taraması yapılarak ve yönetmelikler araştırılarak İSG mevzuatı hakkında bilgi toplanmış ve bu bilgiler doğrultusunda anket soruları hazırlanmıştır. $\mathrm{Bu}$ araştırma çalışması betimsel bir alan çalışması olup, çalışma kaynak tarama ve anket yöntemi kullanılarak yapılmıştır. Anket, Çanakkale Onsekiz Mart Üniversitesi’nin farklı 
birimlerinde çalışan akademik ve idari personel ile yüz yüze görüşülerek gerçekleştirilmiştir. Çalışma sonunda elde edilen veriler, demografik (cinsiyet, bölüm, medeni durum, unvan gibi) özellikleri dikkate alınarak çalıșanların İSG konusundaki bilgi düzeyleri ve farkındalıkları tablolar halinde verilmiştir (Baş, 2008).

Çalışma sonucunda elde edilen verilerin geçerlilik ve güvenilirlik analizi SPSS (IBM SPSS Statistics 24) programı ile yapılmıştır (Büyüköztürk, 2013).

Çalışmada minimum, maksimum, standart hata, frekans ve yüzde ölçüleri kullanılmıştır. Ayrıca çalışmada ortalamaları kıyaslamak amacıyla parametrik testlerden bağımsız örneklem t-testi uygulanmıştır (Can, 2014).

\subsection{Araştırmanın Kapsamı ve Sınırlılıkları}

Bu çalışmada kullanılan anket 2017 yılında Çanakkale Onsekiz Mart üniversitesinde farklı fakülte ve birimlerde çalışanlardan rasgele seçilen 91 akademik ve 86 idari personele uygulanmıştır. \%95 güven aralığında ve \%10 kabul edilebilir hata payı olarak toplam 177 bireye ait örneklem oluşturulmuştur.

Anketteki bă̆ımsız değişkenler:

-Yaş -Cinsiyet -Toplam çalışma yılı -Çalışılan bölüm -Kurumdaki unvan -İSG belgesi olma durumu -İs kazası geçirme durumu -Meslek hastalığına sahip olma durumu

\section{Anketteki bă̆ımlı değişkenler:}

İSG tutumları

Ankette bilgi düzeyini ölçmek için 4'lü ve 5'li likert ölçeği kullanılarak farklı İSG alanlarındaki bilgiler değerlendirilmiştir. Bu alanlar; ISG eğitim ve genel bilgiler (19 soru), fiziksel risk etmenleri (5 soru), psikososyal risk etmenleri (12 soru), ofis ortamı ve oturma düzenini (13 soru) içermektedir.

\section{Araştırma Bulguları ve Tartışma}

\subsection{Katılımcılara Ait Demografik Bulgular}

Araştırma çalışması kapsamında hazırlanan ankete 177 üniversite çalışanı katılmış ve anketin tümü geçerli kabul edilmiştir (Çizelge 3.1).

Çizelge 3.1. Geçerli anket sayısı

\begin{tabular}{|l|c|c|}
\hline & $\mathrm{N}$ & $\%$ \\
\hline Geçerli & 177 & 100,0 \\
\hline Geçersiz & 0 & 0,0 \\
\hline Toplam & 177 & 100,0 \\
\hline
\end{tabular}

Katılımcıların yaş aralıklarının frekans tablosu Çizelge 3.2'de gösterilmiştir. Buna göre 17 kişi 19-25 yaş aralığında, 58 kişi 26-32 yaş aralığında, 65 kişi 33-39, 21 kişi 40-46, 12 kişi 47-53, 2 kişi 54-60 ve 2 kişi de 61-67 yaş aralığındadır. Katılımcı personelin toplam çalışma yıl aralıkları ise Şekil 1'de gösterilmektedir. Buna göre toplam 94 kişi ile 1-6 yıl aralığında çalışanların sayısı en fazladır. Bunu 35 kişi ile 7-12 yıl arası çalışma hayatı olanlar takip etmektedir. Katılımcılardan 23 kişi ise 13-18 yıl arasında çalışma hayatı olan kişilerdir. 
Çizelge 3.2. Katılımcıların yaş aralıklarının frekansı

\begin{tabular}{|l|c|c|c|}
\hline Yaş aralı̆̆ & Frekans & Yüzde & Birikimli yüzde \\
\hline $19-25$ & 17 & 9,6 & 9,6 \\
\hline $26-32$ & 58 & 32,8 & 42,4 \\
\hline $33-39$ & 65 & 36,7 & 79,1 \\
\hline $40-46$ & 21 & 11,9 & 91,0 \\
\hline $47-53$ & 12 & 6,8 & 97,7 \\
\hline $54-60$ & 2 & 1,1 & 98,9 \\
\hline $61-67$ & 2 & 1,1 & 100,0 \\
\hline Toplam & 177 & 100,0 & \\
\hline
\end{tabular}

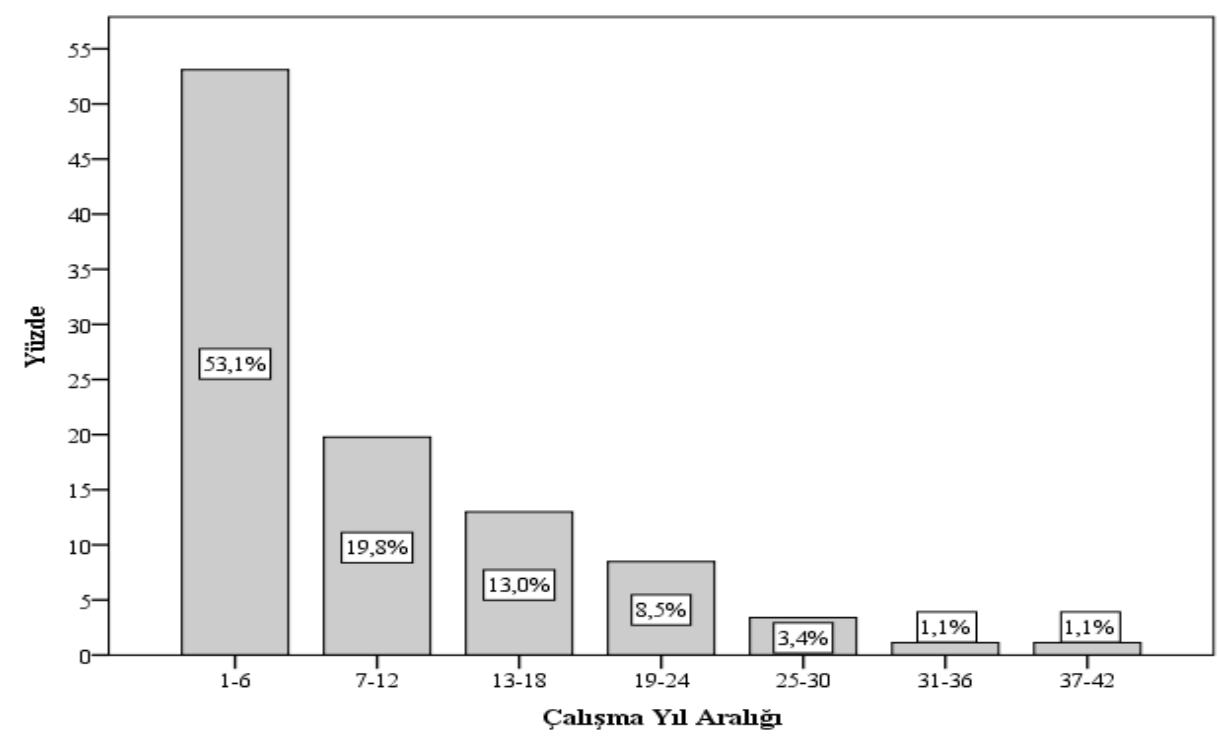

Şekil 3.1. Katılımcıların toplam çalışma yıl aralıkları yüzde dağılımı

91 akademik personelin unvanlara göre dağılımı incelendiğinde 4 kişinin Okutman, 50 kişinin Araştırma Görevlisi, 8 kişinin Öğretim Görevlisi, 2 kişinin Uzman, 20 kişinin Yardımcı Doçent, 4 kişinin Doçent ve 3 kişinin Profesör olduğu (Çizelge 3.3), 177 katılımcıdan da yalnızca 18'nin İSG belgesine sahip olduğu görülmüştür (Çizelge 3.4).

Çizelge 3.3. Katılımcıların unvanlara göre dağılımı

\begin{tabular}{|l|c|c|c|}
\hline Unvan & Frekans & Yüzde & Birikimli yüzde \\
\hline İdari Personel & 86 & 48,6 & 48,6 \\
\hline Araştırma Görevlisi & 50 & 28,2 & 76,8 \\
\hline Yardımcı Doçent & 20 & 11,3 & 88,1 \\
\hline Öğretim Görevlisi & 8 & 4,5 & 92,6 \\
\hline Doçent & 4 & 2,3 & 94,9 \\
\hline Okutman & 4 & 2,3 & 97,2 \\
\hline Profesör & 3 & 1,7 & 98,9 \\
\hline Uzman & 2 & 1,1 & 100,0 \\
\hline Toplam & 177 & 100,0 & \\
\hline
\end{tabular}


Çizelge 3.4. İSG belgesine sahip olma

\begin{tabular}{|l|c|c|c|}
\hline & Frekans & Yüzde & Birikimli yüzde \\
\hline Evet & 18 & 10,2 & 10,2 \\
\hline Hayır & 159 & 89,8 & 100,0 \\
\hline
\end{tabular}

\subsection{Anket Sorularına İlişkin Bulgular}

Üniversite çalışanlarından idari ve akademik personele yöneltilen İSG hakkındaki bilgi düzeylerini ve farkındalıklarını ölçmek adına sorulan sorulardan bir kısmı bu bölümde gösterilecektir. Sorulardan bazılarında Hiç (1), Az (2), Orta (3), Çok (4) şeklinde derecelerle derecelendirilmiş ve puanlanmıştır. Bazılarında ise Tamamen Katılıyorum (1), Katılıyorum (2), Kararsızım (3), Katılmıyorum (4), Kesinlikle Katılmıyorum (5) derecelerle derecelendirilmiş ve puanlanmıştır. Anketteki bazı sorular ise çok seçimli soru tiplerindendir.

Katılımcılara yöneltilen "Çalıştığım kurumda İSG alanında seminer/(bilgilendirme) aldım" sorusuna verilen cevaplar Çizelge 3.5'de görülmektedir. Verilen cevapların ortalama değeri 2,2'dir. Görüldüğg̈ üzere katılımcıların \%32,2'si ISG yönelik hiçbir seminer almadığını söylemektedir. Katılımcıların toplamda $\% 54,8$ 'i ISG hakkında az ya da orta seviyede bilgilendirme aldığını söylemiştir. 177 katılımcıdan yalnızca 18 'i İSG belgesine sahiptir. Bu da toplam katılımcıların \%10,2'sine tekabül etmektedir.

Çizelge 3.5. İSG alanında seminer alma

\begin{tabular}{|l|c|c|c|}
\hline & Frekans & Yüzde & Birikimli yüzde \\
\hline Hiç & 57 & 32,2 & 32,2 \\
\hline $\mathrm{Az}$ & 36 & 20,3 & 52,5 \\
\hline Orta & 61 & 34,5 & 87,0 \\
\hline Çok & 23 & 13,0 & 100,0 \\
\hline
\end{tabular}

Katılımcılara yöneltilen “6331 sayılı İSG Kanunu hakkında bilgi düzeyim” sorusuna verilen cevaplar Çizelge 3.6'da gösterilmiştir. Verilen cevapların ortalama değeri 2,2'dir. Katılımcıların büyük çoğunluğunu oluşturan \%37,3'lük kısmı İSG kanunu hakkında bilgi düzeylerinin az olduğunu söylerken katılımcıların \%20,9'u hiç bilgilerinin olmadığını belirtmiştir. Katılımcıların sadece \%7,9'u İSG kanunu hakkında bilgi düzeylerinin çok olduğunu belirtmiştir.

Çizelge 3.6. 6331 sayılı İSG kanunu hakkında bilgi düzeyleri

\begin{tabular}{|l|c|c|c|}
\hline & Frekans & Yüzde & Birikimli yüzde \\
\hline Hiç & 37 & 20,9 & 20,9 \\
\hline Az & 66 & 37,3 & 58,2 \\
\hline Orta & 60 & 33,9 & 92,1 \\
\hline Çok & 14 & 7,9 & 100,0 \\
\hline
\end{tabular}

Katılımcıların \%17,5'i iş kazası hakkında çok bilgiye sahip olduğunu, \%5,6'sı ise iş kazası ile ilgili hiç bilgilerinin olmadığını söylemektedirler (Çizelge 3.7). Katılımcıların \%32,2'si iş kazası hakkındaki bilgi düzeyine az derken, \%44,6's1 orta cevabını vermiştir. Verilen cevapların ortalama değerleri ise 2,7'dir. Katılımcıların meslek hastalığı hakkındaki bilgi düzeyleri Çizelge 3.8'de gösterilmiştir Katılımcıların \%16,9'u meslek hastalığı hakkında çok bilgiye sahiptir. Katılımcıların \%7,3'ü ise meslek hastalığı hakkında hiç bilgiye sahip değildir. Verilen cevapların ortalama değerleri ise 2,6 'dır. 
Çizelge 3.7. Katılımcıların iş kazası hakkındaki bilgi düzeyleri

\begin{tabular}{|l|c|c|c|}
\hline & Frekans & Yüzde & Birikimli yüzde \\
\hline Hiç & 10 & 5,6 & 5,6 \\
\hline $\mathrm{Az}$ & 57 & 32,2 & 37,9 \\
\hline Orta & 79 & 44,6 & 82,5 \\
\hline Çok & 31 & 17,5 & 100,0 \\
\hline
\end{tabular}

Çizelge 3.8. Katılımcıların meslek hastalığı hakkındaki bilgi düzeyleri

\begin{tabular}{|l|c|c|c|}
\hline & Frekans & Yüzde & Birikimli yüzde \\
\hline Hiç & 13 & 7,3 & 7,3 \\
\hline $\mathrm{Az}$ & 69 & 39,0 & 46,3 \\
\hline Orta & 65 & 36,7 & 83,1 \\
\hline Çok & 30 & 16,9 & 100,0 \\
\hline
\end{tabular}

Katılımcılara yöneltilen "Çalıştığım kurumdaki iş güvenliği önlemlerinin uygulanma düzeyi” sorusuna verilen cevapların ortalama değeri 2,5'dir (Çizelge 3.9). Katılımcıların büyük çoğunluğunu oluşturan \%44,6's1 önlemlerin orta seviyede olduğunu belirtirken, \%11,3'ü İSG önlemlerinin uygulanma düzeyinin hiç olmadığını, \%13'ü ise önlemlerin uygulanma düzeyinin çok iyi olduğunu belirtmiştir.

Çizelge 3.9. Çalışılan kurumdaki İSG önlemlerinin uygulanma düzeyine ilişkin görüşler

\begin{tabular}{|l|c|c|c|}
\hline & Frekans & Yüzde & Birikimli yüzde \\
\hline Hiç & 20 & 11,3 & 11,3 \\
\hline $\mathrm{Az}$ & 55 & 31,1 & 42,4 \\
\hline Orta & 79 & 44,6 & 87,0 \\
\hline Çok & 23 & 13,0 & 100,0 \\
\hline
\end{tabular}

Katılımcılara yöneltilen "Çalışma ortamındaki uyarıcı levha ve işaretlerinin ne anlama geldiği hakkındaki bilgi düzeyim" sorusuna verilen cevapların ortalama değeri 3,1'dir. Katılımcıların büyük çoğunluğunu oluşturan \%46,9'u işaret ve levhaların anlamlarını orta seviyede bildiğini, \%35,6'sı ise çok bildiğini söylemiştir. Katılımcıların yalnızca \% 1,7'si levha ve işaretlerin ne anlama geldiğini hiç bilmemektedir (Çizelge 3.10). Uyarı işaret ve levhalarının diğer sorulara göre daha çok biliniyor olmasının sebebi, görsel hafızanın daha kalıcı olmasıdır.

Çizelge 3.10. Çalışma ortamındaki uyarıcı levha ve işaretlerinin ne anlama geldiği hakkındaki bilgi düzeyleri

\begin{tabular}{|l|c|c|c|}
\hline & Frekans & Yüzde & Birikimli yüzde \\
\hline Hiç & 3 & 1,7 & 1,7 \\
\hline $\mathrm{Az}$ & 28 & 15,8 & 17,5 \\
\hline Orta & 83 & 46,9 & 64,4 \\
\hline Çok & 63 & 35,6 & 100,0 \\
\hline
\end{tabular}

Çizelge 3.11 ve 3.12 incelendiğinde katılımcıların yaklaşık \%46,3'ü yangın, \%45,8'i deprem esnasında yapılması gerekenler hakkında orta seviyede bilgi sahibi olduğunu belirtirken, \%3,4'lük kısmın ise yangın ve deprem sırasında yapılacaklar hakkında hiç bilgisi olmadığı ortaya çıkmıştır. Verilen cevapların ortalama değerleri ise sırasıyla 2,9 ve 3,1'dir. 
Çizelge 3.11. Yangın esnasında yapılması gerekenler hakkındaki bilgi düzeyleri

\begin{tabular}{|l|c|c|c|}
\hline & Frekans & Yüzde & Birikimli yüzde \\
\hline Hiç & 6 & 3,4 & 3,4 \\
\hline $\mathrm{Az}$ & 39 & 22,0 & 25,4 \\
\hline Orta & 82 & 46,3 & 71,8 \\
\hline Çok & 50 & 28,2 & 100,0 \\
\hline
\end{tabular}

Çizelge 3.12. Deprem esnasında yapılması gerekenler hakkındaki bilgi düzeyleri

\begin{tabular}{|l|c|c|c|}
\hline & Frekans & Yüzde & Birikimli yüzde \\
\hline Hiç & 6 & 3,4 & 3,4 \\
\hline $\mathrm{Az}$ & 27 & 15,3 & 18,6 \\
\hline Orta & 81 & 45,8 & 64,4 \\
\hline Çok & 63 & 35,6 & 100,0 \\
\hline
\end{tabular}

Katılımcılara "Aşağıdaki rahatsızlıklardan sizde mevcut olan var mı? Var ise hangisi/ hangileri?" şeklinde çok seçenekli soru yöneltilmiştir. Katılımcıların \%14,1 gibi büyük bir çoğunluğunda "sırt ağrısı" gözlemlenmiştir. Katılımcıların toplamda \%25,4'ünde boyun ve s1rt ağrısı görülmüştür. Katılımcıların \%13,6'sında "genel yorgunluk hali" mevcut iken \%8'inde uyku bozukluğu görülmektedir (Şekil 3.2). İSG alanının ergonomi ve psikososyal yönleri de olduğu düşünülürse bu rakamlar üzerinde çalışılması gereken rakamlardır. Çalışma ortamının psikososyal yapısı ve ergonominin çalışma performansına etkisi oldukça fazladır. $\mathrm{Bu}$ tarz olumsuzlukların azaltılmasının verimliliği artıracağı bilinmektedir. 


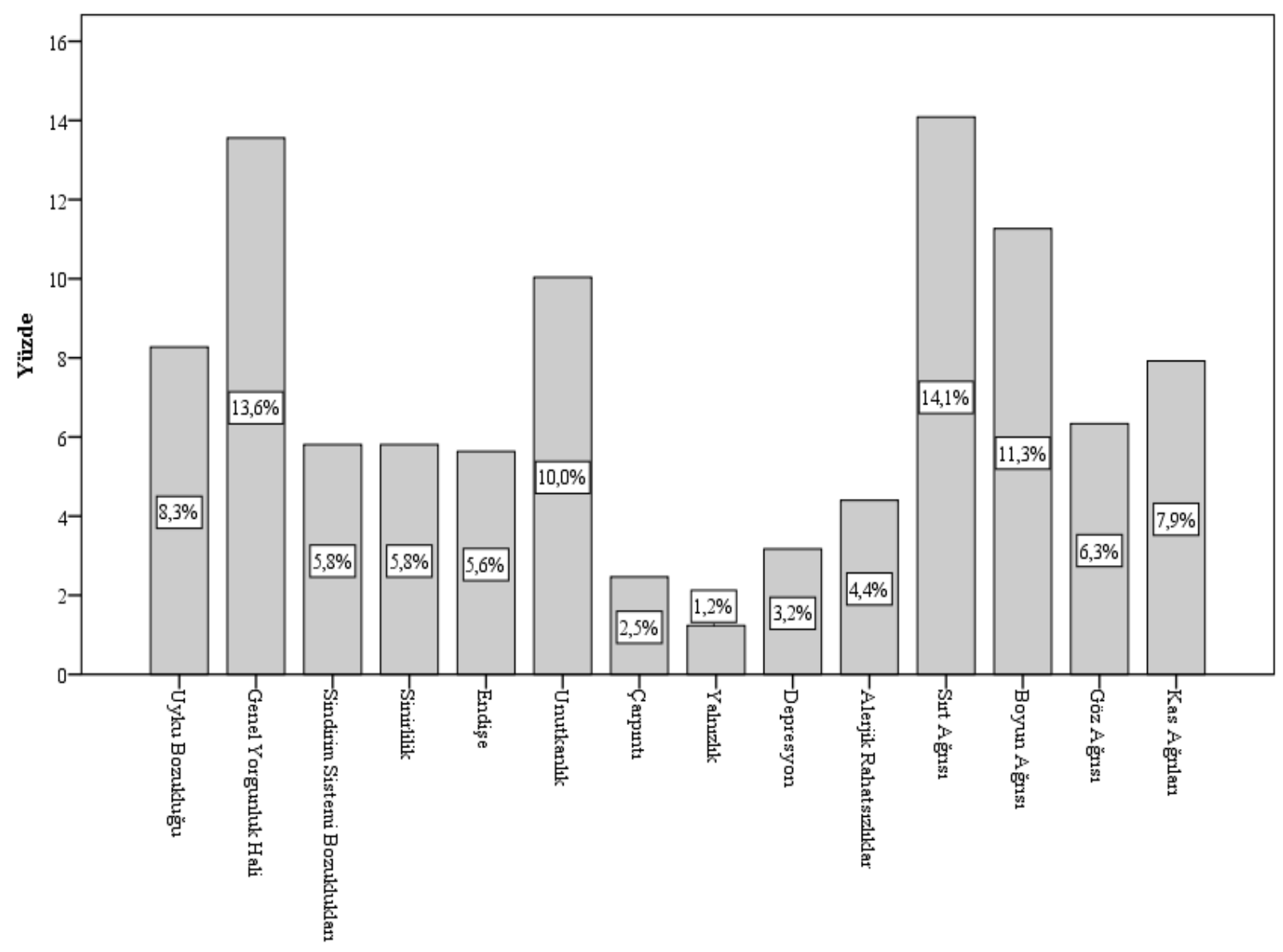

Şekil 3.2. Kas iskelet sistemi rahatsızlıklara sahip olanların yüzde dağılımı

177 katılımcıya "İş Kazalarının nedenleri size göre nelerdir?” şeklinde çok seçenekli soru yöneltildiğinde seçilen sebeplerin dağılımı Şekil 3.3'te gösterilmektedir. Buna göre katılımcıların büyük çoğunluğunu oluşturan \%14,7'si “dikkatsizliğin” iş kazalarının en büyük nedeni olduğunu söylemiştir. Dikkatsizliği, \%12,8 ile "eğitimsizlik", \%12,3 ile "tedbirsiz davranışlar" ve \%11,2 ile "yoğun iş temposu" izlemektedir. 


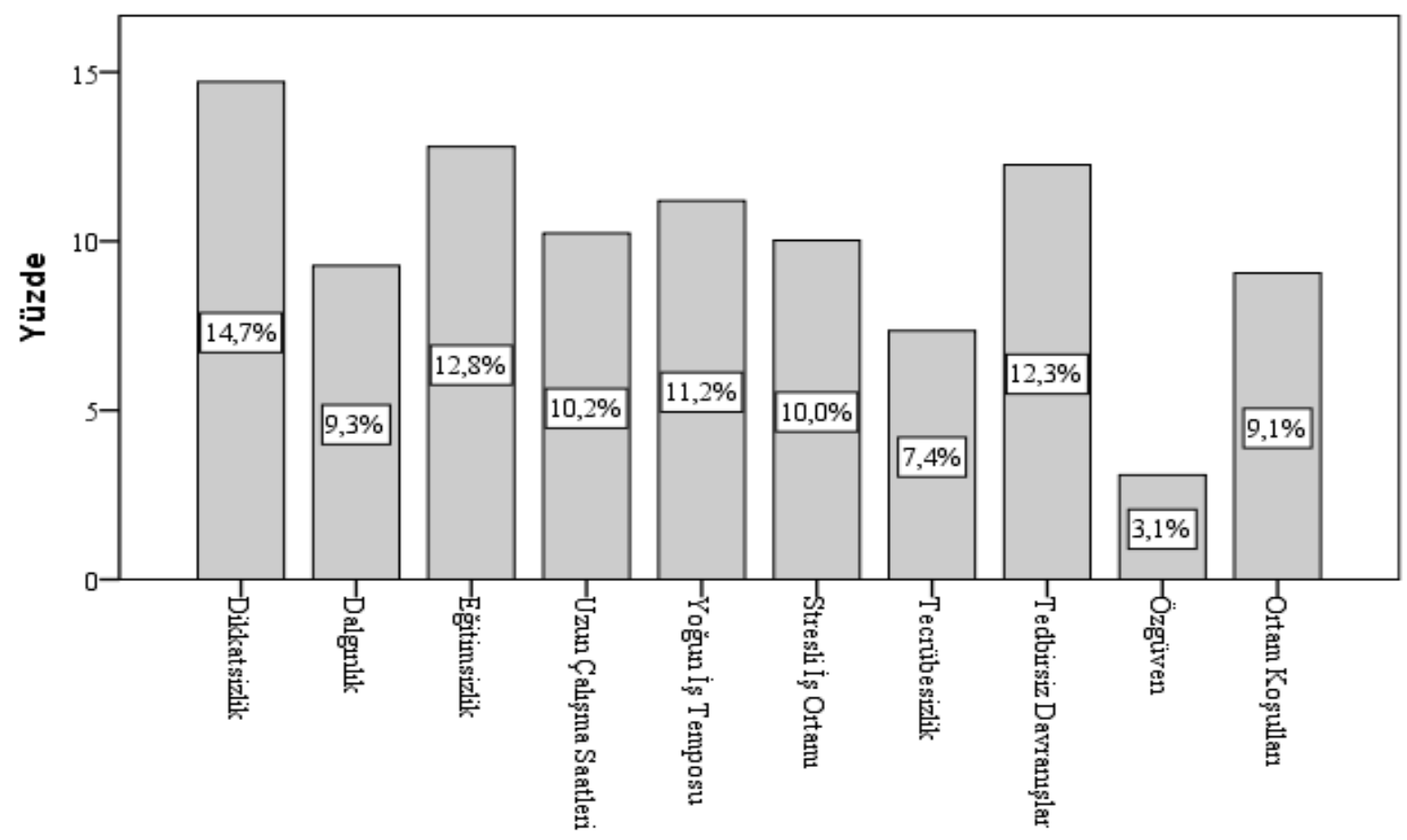

Şekil 3.3. İş kazalarının nedenleri size göre nelerdir sorusuna verilen cevaplar

Katılımcılara "ISSG açısından görev hak ve sorumluluklarımı biliyorum.” şeklinde likert ölçeği şeklinde soru yöneltilmiştir. Verilen yanıtların dağglımı Çizelge 3.13'te verilmiştir. Verilen cevapların ortalama değeri 2,8'dir. Katılımcıların \%26's1 "kararsızım" cevabını verirken, toplamda \%25,4'ünün görev hak ve sorumluluklarını bilmediğini tespit edilmiştir.

Çizelge 3.13. 'ISSG açısından görev hak ve sorumluluklarımı biliyorum.' sorusunun cevap dağılımı

\begin{tabular}{|l|c|c|}
\hline & Frekans & Yüzde \\
\hline Tamamen katıliyorum & 13 & 7,3 \\
\hline Katıliyorum & 73 & 41,2 \\
\hline Kararsızım & 46 & 26,0 \\
\hline Katılmiyorum & 35 & 19,8 \\
\hline Kesinlikle katılmiyorum & 10 & 5,6 \\
\hline
\end{tabular}

“İSG ile ilgili mevzuata ulaşma ihtiyacı duyduğunuzda en çok faydalandığınız kaynak nedir?" sorusuna verilen cevapların frekans dağılımı ve yüzde dağılım grafiği Şekil 3.4'te verilmiştir. Buna göre katılımcıların ISG hakkında en çok faydalandığı kaynağın \%62,1 ile internet olduğu görülmektedir. Katılımcıların \%2,4'lük kısım ise İSG mevzuatına ulaşma ihtiyacı duymamıştır. Sendikalar ve kurum içi yazışmalar ise ISG mevzuatı yönünden en az faydalanılan kaynaklar olarak ortaya çıkmıştır. 


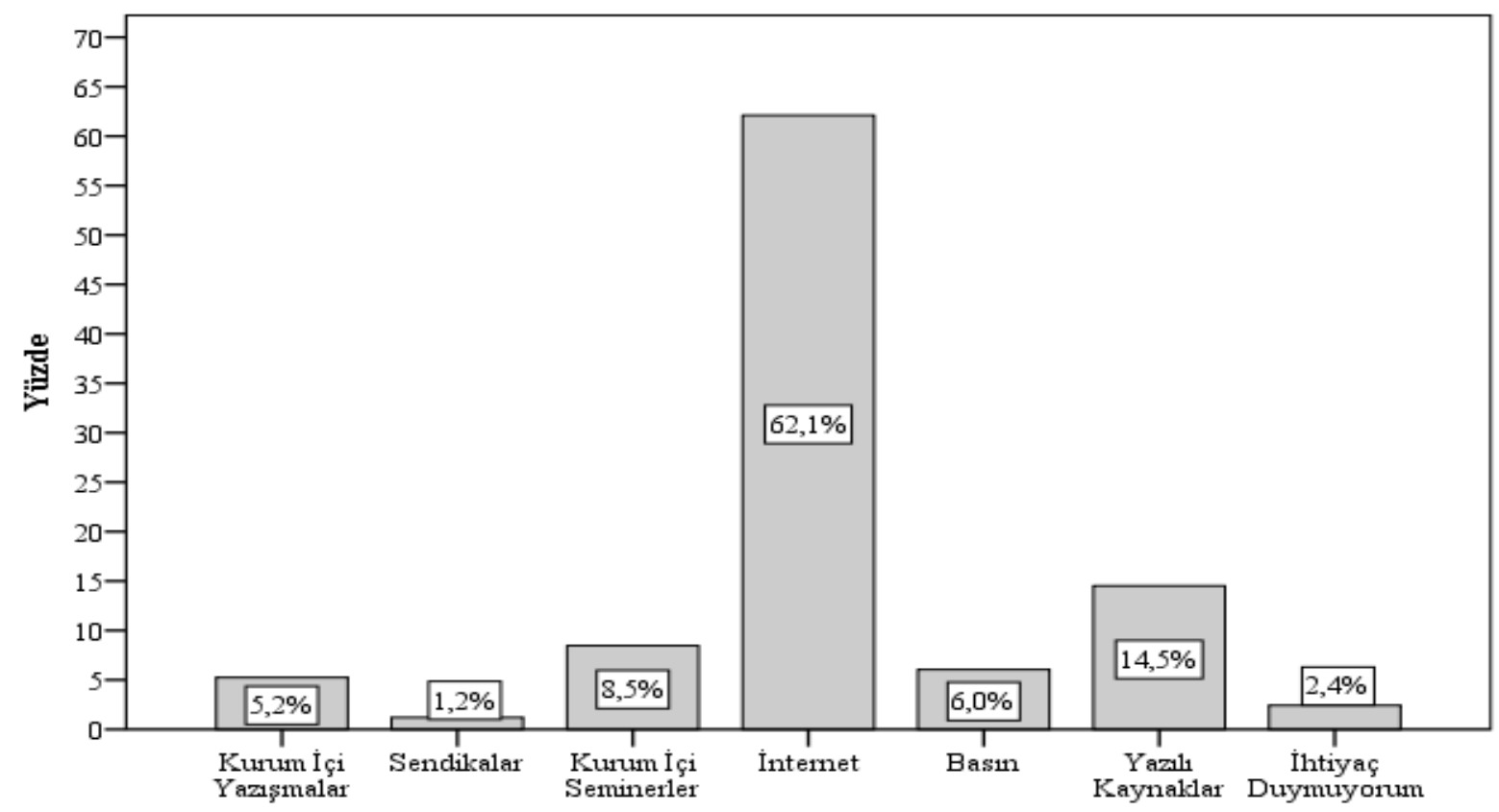

Şekil 3.4. İSG ile ilgili mevzuata ulaşma ihtiyacı duyduğunuzda en çok faydalandığınız kaynak nedir sorusuna verilen cevaplar

\subsection{Anket Sorularına İlişkin Bağımsız t-Testi}

Bir hipotez testinde iki hipotez yer alır: Araştırma hipotezi ve yokluk hipotezi $\left(\mathrm{H}_{0}\right)$ Araştırmacının bir kuramdan bir olgudan yola çıkarak düşündüğü doğru olduğuna inandığı hipoteze araştırma (karşıt) hipotezi denir. Hipotezin doğruluğuna karar verme işi sıfır hipotezin kabul ve reddedilmesi yoluyla yapılır (Ünver ve ark., 2013).

Art arda yapılan ölçümler arasındaki tutarlılık ya da kararlılık güvenirlik olarak adlandırılır. Ölçümlerde güvenirlilik, güvenirlilik katsayısı $(\alpha)$ adı verilen bir sayı ile ifade edilir. Çoğunlukla güvenirlilik katsayısı 0 ile +1 arasında bir değer alır ve 1'e ne kadar yaklaşırsa, güvenirliğin arttığını anlamını gösterir. $\alpha$ değerinin yorumlanması aşağıda belirtildiği gibidir.

$0,00 \leq \alpha<0,40$ Güvenilir değil

$0,40 \leq \alpha<0,60$ Düşük derecede güvenilir

$0,60 \leq \alpha<0,90$ Oldukça güvenilir

$0,90 \leq \alpha<1,00$ Yüksek derecede güvenilir (Tavşanc1l, 2006)

Çizelgede 3.14'de görüldüğü üzere ankette ölçekteki madde sayısı 49'dur. Ölçeğin Cronbach Alpha güvenirlik katsayısı $\alpha=0,849$ gibi güvenilir sayılan bir değer çıkmıştır.

Çizelge 3.14. Anketin güvenirlilik analizi

\begin{tabular}{|c|c|}
\hline Cronbach's alpha & Değerlendirmeye katılan soru sayısı $(\mathrm{N})$ \\
\hline 0,849 & 49 \\
\hline
\end{tabular}

"Çalıştığım kurumda İSG alanında seminer (bilgilendirme) aldım” soru cümlesine ait puanların çalışanların İSG belgelerinin olma durumları değişkeninin üzerinde anlamlı bir etkisinin olup olmadığını ortaya koymak için yapılan bağımsı grup t-testi sonucunda $p$ değeri 0,035 olarak bulunmuştur. Buna göre $\mathrm{p}<0,05 \mathrm{t}=2,12$ olduğu için $\mathrm{H}_{0}$ hipotezi reddedilir. $\mathrm{Bu}$ durumda katılımcıların İSG belgeleri olma durumları değişkeni ile çalıştığım kurumda İSG 
alanında seminer (bilgilendirme) aldım sorusuna ait puanların arasında istatistiksel olarak anlamlı fark bulunmuştur. İSG belgesine sahip olanların olmayanlara göre daha fazla seminer bilgilendirme aldıkları söylenebilir (Çizelge 3.15).

Çizelge 3.15. Seminer alma durumu ile İSG belgesine sahip olma değişkeni arasındaki bağımsız t-testi analiz sonucu

\begin{tabular}{|l|c|c|c|c|c|c|}
\hline & $\mathrm{N}$ & $X$ & Ss & $\mathrm{F}$ & $\mathrm{t}$ & $\mathrm{p}$ \\
\hline Evet & 18 & 2,777 & 1,060 & \multirow{2}{*}{0,388} & 2,122 & 0,035 \\
\hline Hayır & 159 & 2,226 & 1,042 & & & \\
\hline
\end{tabular}

$\mathrm{H}_{0}$ : Ankete katılanların İSG farkındalığına ilişkin soru ile İSG belgesine sahip olma durumu arasında anlamlı bir ilişki yoktur.

$\mathrm{H}_{1}$ : Ankete katılanların ISG farkındalığına ilişkin soru ile İSG belgesine sahip olma durumu arasında anlamlı bir ilişsi vardır.

“6331 sayılı İSG Kanunu hakkında bilgi düzeyim” soru cümlesine ait puanların, çalışanların İSG belgelerinin olma durumları değişkeninin üzerinde anlamlı bir etkisinin olup olmadığını ortaya koymak için yapılan bağımsız grup $t$ testi sonucunda $p$ değeri 0,006 bulunmuştur (Çizelge 3.16). Buna göre $\mathrm{p}<0,05 \mathrm{t}=2,806$ olduğu için $\mathrm{H}_{0}$ hipotezi reddedilir, bu durumda katılımcıların İSG belgeleri olma durumları değişkeni ile ISG kanunu hakkında bilgi düzeyi sorusuna ait puanların arasında istatistiksel olarak anlamlı fark bulunmuştur. İSG belgesine sahip personelin ortalaması $(2,83)$ sahip olmayanların ortalamasından $(2,26)$ yüksek olduğu görülmektedir. Bunun sonucunda ISSG belgesine sahip olanların olmayanlara göre İSG kanunu hakkında bilgi düzeylerinin daha fazla olduğu söylenebilir.

Çizelge 3.16. İSG kanunu hakkında bilgi düzeyleri ile İSG belgesine sahip olma değişkeni arasındaki bağımsız t-testi analiz sonucu

\begin{tabular}{|l|c|c|c|c|c|c|}
\hline & $\mathrm{N}$ & $X$ & Ss & $\mathrm{F}$ & $\mathrm{t}$ & $\mathrm{p}$ \\
\hline Evet & 18 & 2,833 & 0,707 & \multirow{2}{*}{4,289} & 2,806 & 0,006 \\
\cline { 1 - 5 } Hayır & 159 & 2,226 & 0,885 & & & \\
\hline
\end{tabular}

$\mathrm{H}_{0}$ : Ankete katılanların İSG farkındalığına ilişkin soru ile İSG belgesine sahip olma durumu arasında anlamlı bir ilişki yoktur.

$\mathrm{H}_{1}$ : Ankete katılanların İSG farkındalığına ilişkin soru ile İSG belgesine sahip olma durumu arasında anlamlı bir ilişki vardır.

“İş kazası hakkında bilgi düzeyim” soru cümlesine ait puanların, çalışanların İSG belgelerinin olma durumları değişkeninin üzerinde anlamlı bir etkisinin olup olmadığını ortaya koymak için yapılan bağımsız grup t testi sonucunda $\mathrm{p}$ değeri 0,008 bulunmuştur (Çizelge 3.17). Buna göre $\mathrm{p}<0,05 \mathrm{t}=2,70$ olduğu için $\mathrm{H}_{0}$ hipotezi reddedilir, bu durumda katılımcıların İSG belgeleri olma durumları değișkeni ile iş kazası hakkında bilgi düzeyi sorusuna ait puanların arasında istatistiksel olarak anlamlı fark bulunmuştur. ISG belgesine sahip personelin ortalaması $(3,22)$ sahip olmayanların ortalamasından $(2,68)$ yüksek olduğu görülmektedir. Bunun sonucunda İSG belgesine sahip olanların olmayanlara göre iş kazası hakkında bilgi düzeylerinin daha yüksek olduğu söylenebilir. 
Çizelge 3.17. İş kazası hakkında bilgi düzeyi ile İSG belgesine sahip olma değişkeni arasındaki bağımsız t-testi analiz sonucu

\begin{tabular}{|l|c|c|c|c|c|c|}
\hline & $\mathrm{N}$ & $X$ & $\mathrm{Ss}$ & $\mathrm{F}$ & $\mathrm{t}$ & $\mathrm{p}$ \\
\cline { 1 - 4 } Evet & 18 & 3,22 & 0,646 & \multirow{2}{*}{2,515} & 2,705 & 0,008 \\
\cline { 1 - 5 } Hayir & 159 & 2,685 & 0,812 & & & \\
\hline
\end{tabular}

$\mathrm{H}_{0}$ : Ankete katılanların İSG farkındalığına ilişkin soru ile İSG belgesine sahip olma durumu arasında anlamlı bir ilişki yoktur.

$\mathrm{H}_{1}$ : Ankete katılanların İSG farkındalığına ilişkin soru ile İSG belgesine sahip olma durumu arasında anlamlı bir ilişki vardır.

"Meslek hastalıkları hakkında bilgi düzeyim" soru cümlesine ait puanların çalışanların iş kazası geçirme değişkeninin üzerinde anlamlı bir etkisinin olup olmadığını ortaya koymak için yapılan bağımsız grup t-testi sonucunda $p$ değeri 0,009 bulunmuştur. Buna göre $p<0,05$ $\mathrm{t}=2,65$ olduğu için $\mathrm{H}_{0}$ hipotezi reddedilir, bu durumda katılımcıların iş kazası geçirme değişkeni ile meslek hastalıkları hakkında bilgi düzeyi sorusuna ait puanların arasında istatistiksel olarak anlamlı fark bulunmuştur. İş kazası geçiren çalışanların, geçirmeyenlere göre meslek hastalıkları hakkında bilgi düzeylerinin daha fazla olması kaza sonrası İSG ile ilgili olarak araştırma yapmalarından kaynaklandığını söylemek mümkündür (Çizelge 3.18).

Çizelge 3.18. İş kazası hakkında bilgi düzeyi ile İSG belgesine sahip olma değişkeni arasındaki bağımsız t-testi analiz sonucu

\begin{tabular}{|l|c|c|c|c|c|c|c|}
\hline & & $\mathrm{N}$ & $X$ & $\mathrm{Ss}$ & $\mathrm{F}$ & $\mathrm{t}$ & $\mathrm{p}$ \\
\hline Evet & & 12 & 3,250 & 0,621 & \multirow{2}{*}{3,579} & 2,650 & 0,009 \\
\cline { 1 - 7 } Hayır & & 165 & 2,578 & 0,848 & & & \\
\hline
\end{tabular}

$\mathrm{H}_{0}$ : Ankete katılanların İSG farkındalığına ilişkin soru ile iş kazası geçirme durumu arasında anlamlı bir ilişki yoktur.

$\mathrm{H}_{1}$ : Ankete katılanların İSG farkındalığına ilişkin soru ile iş kazası geçirme durumu arasında anlamlı bir ilişki vardır.

\section{Sonuç}

İş kazaları ve meslek hastalıkları çalışanların tehlikeli hareketleri ve işyeri ortamındaki tehlikeli durumların bir araya gelmesi sonucu meydana gelmektedir. İş sağlıği ve güvenliği, çeşitli endüstri ve faaliyetlere özgü olarak tıp, psikoloji, toksikoloji, ergonomi, fizik, kimya ekonomi hukuk, teknoloji gibi bilimsel alanlarla ilgili konuları da içeren geniş kapsamlı ve çok disiplinli bir kavramdır. Çalışanların iş sağlığı ve güvenliği bilincine sahip olmasında, bilgi düzeylerinin geliştirilmesinde ve davranışlarının şekillendirilmesinde İSG eğitimlerinin önemi oldukça büyüktür. Bu yüzden son yıllarda ISG eğitimlerine olan ilgi artmıştır. $\mathrm{Bu}$ çalışmada, Çanakkale Onsekiz Mart Üniversitesi kamu çalışanlarının İSG eğitimleri alanında farkındalıklarının belirlenmesi için bir anket çalışması yapılmıştır. Çalışma sonucunda elde edilen veriler SPSS programı ile analiz edilmiştir. Ankete 91 akademik, 86 idari personel katılmıştır. Araştırmaya katılan çalışanların 81'i $(\% 45,8)$ erkek, 96'sı $(\% 54,2)$ kadındır. Yaş ortalaması $34,5 \pm(8,2)$ 'dir. Toplam çalışma yıl ortalaması $9,3 \pm(7,7)$ 'dir. Soruların güvenirlik analizi $\alpha=0,849$ 'dur. 
Araştırmaya katılanların çoğunun İSG konusunda yeterli bilgiye sahip olmadıkları ve çalıştıkları kurumda iş güvenliği önlemlerinin uygulanma düzeyinin oldukça düşük olduğu tespit edilmiştir. İSG eğitimleri çalışanların bilinç düzeylerini arttırarak iş kazaları ve meslek hastalıklarını ortadan kaldırmayı veya en aza indirmeyi hedefleyen bir süreçtir. İş kazaları ve meslek hastalıklarından korunmak için alınabilecek en önemli tedbirin eğitim olduğunu söylemek yanlış olmaz. Bundan dolayı, işverenler eğitim ile çalışanlarda iş güvenliği bilincini, kültürünü ve davranışını bir yaşam şekline getirmeyi amaçlamalıdır.

Katılımcılarda en çok sırt, boyun ağrısı ve genel yorgunluk hali rahatsızlıklarının olduğu tespit edilmiştir. Bunun nedeninin ergonomik çalışma koşullarının tam olarak sağlanmamış olmasından kaynaklandığı söylenebilir. Buna yönelik olarak ofislerdeki ergonomik risk faktörlerinin belirlenip bu risklere karşı önlem alınması gerekmektedir. Böylece çalışanların güvenliği sağlandığı gibi iş veriminde artış sağlanır. Ayrıca, masa başında çalışanların herhangi bir meslek hastalığına yakalanmamaları için belirli aralıklarda yapmaları gereken egzersiz hareketleri ile ilgili eğitimler verilmelidir.

İSG ile ilgili mevzuata/bilgilere ulaşmak için katılımcıların en çok kullandıkları kaynağın internet olduğunu görülmüştür. Bu bilgi göz önüne alındığında kurum tarafından hazırlanacak bilgilendirme seminerleri, görsel ve işitsel videolar, interaktif eğitim metotları çevrimiçi olarak çalışanlara sunulabilir. Böylece, çalışanların internet ortamındaki kaynak arayışında güvenilir bilgiye doğrudan kurum vasıtasıyla ulaşması sağlanabilir. Ayrıca internet ortamında ulusal bir bilgi ağı da oluşturulmalıdır.

Katılımcıların yaklaşık \%12,8'i iş kazalarının nedenlerinin eğitimsizlikten kaynaklandığını belirtmiştir. Kurumlarda İSG eğitimlerinin bir plan halinde yürütülmesi sağlanmalı ve ISSG uygulamalarının yaşam biçimi haline getirilmesi için kurumların gereken çabayı göstermesi gerekmektedir. İşverenler, birim farkı gözetmeksizin tüm çalışanlara yönelik İSG eğitimleri belirli aralıklarla alanında uzman kişilerce verilmesini sağlamalıdır. Çünkü İSG eğitimleri sonucunda çalışanların iş sağlığı ve güvenliğine dair bilgi ve becerileri artmakta, yaptıkları işlere ilişkin riskleri fark ederek hem kendilerinin hem de diğer çalışanların hayatını tehlikeye sokacak güvensiz hareketlerden kaçınmaktadırlar. ISG alanına yönelik farkındalığı artırmak için bazı farklı stratejiler de uygulanabilir. Örnek olarak posterler, logolar, görsel ve işitsel araçlar, kurum içi seminerler, kamu spotları verilebilir. 


\section{Kaynaklar}

Akgemci T., 1997. İnsan Kaynakları Yönetiminde Eğitim ve Geliştirme Etkenliğinin Sağlanması. Verimlilik Dergisi, 59-61.

Akyiğit E., 2001. İş Kanunu Şerhi. Seçkin Yayınları, Ankara, 48-63.

Akyüz Y., 1993. Türk Eğitim Tarihi. Kültür Koleji Yayınları, Ankara, 145-148.

Alper Y., 1992. İşçi Sağlığı ve İş Güvenliği ile İlgili Problemlere Genel Bir Bakış. Çalışma ve Sosyal Güvenlik Bakanlığı İşçi Sağlığı Daire Başkanlığı Dergisi, 14: 33-38.

Baş T., 2008. Anket Nasıl Hazırlanır, Uygulanır, Değerlendirilir. Seçkin Yayıncılık, İstanbul, 255-260.

Büyüköztürk Ş., 2013. Sosyal Bilimler için Veri Analizi El Kitabı. Pegem Akademi Yayınc1lı, İstanbul, 213-219.

Can A., 2014. SPSS ile Bilimsel Araştırma Sürecinde Nicel Veri Analizi. Pegem Akademi Yayınc1l1k, İstanbul, 393-401.

C11ga E., 2004. İş Sağlığı ve Güvenliğinde Yeni Dönem, Mess Mercek, 34: 108-115.

Demircioğlu M., Centel, T., 2003. İş Hukuku, Beta Yayınları, Ankara, 85-92.

ILO 2015. Investigation of Occupational Accidents and Diseases, (A Practical Guide for Labour Inspectors, Geneva).

Işık R., 2000. İş Sağlığı ve Güvenliği için Öğretim. İş Sağlığı ve Güvenliği Dergisi, Eğitim Özel Sayıs1: 24-27.

Kale Ö., Yanık S., 2018. İnşaat Sektörü Çalışanlarının İşçi Sağlığı ve İş Güvenliği Eğitimleri Konusundaki Bilinç Düzeylerini Ölçmeye Yönelik Bir Sektörel Araştırma. Sakarya Üniversitesi Fen Bilimleri Enstitüsü Dergisi, 22, 2: 639-651.

Montero M. J., Araque R. A., Rey J. M., 2009. Occupational Health and Safety in The Framework of Corporate Social Responsibility. Safety Science, 47,10: 1440-1445.

Özkılıç Ö., 2005. İş Sağlı̆̆ı ve Güvenliği Yönetim Sistemleri ve Risk Değerlendirme. Türkiye İşveren Sendikaları Konfederasyonu Yayınları, 246: 73-77. 
Şerifoğlu U., Kürşat S., 2007. İşletmelerde Sağl1k ve Güvenlik Kültürünün Oluşturulması; Tepe Yönetiminin Rolü ve Kurum İçi İletişim Olanaklarının Kullanımı. İ.Ü. İşletme İktisadı Enstitüsü Yönetim Dergisi, 18, 58: 41-50.

Tanır F., 2004. İşçi Sağlığ1 ve İş Güvenliği. İş Sağlığ1 ve Güvenliği Dergisi, 17-22.

Tavşancıl E., 2006. Tutumların Ölçülmesi ve SPSS ile Veri Analizi. Nobel Yayınları, İstanbul, 123-130.

TDK, 2017. Güncel Türkçe Sözlük (Türk Dil Kurumu) http://www.tdk.gov.tr

Ünver Ö., Gamgam H., Altunkaynak B., 2013. Temel İstatistik Yöntemler. Seçkin Yayıncılık, Ankara, 488-493.

Varış F., 1985. Eğitim Bilimine Giriş. Ankara Üniversitesi Eğitim Bilimleri Fakültesi Yayınları, Ankara, 32-38.

WHO, 2017. Dünya Sağl1k Örgütü (World Health Organization) http://www.who.int/en 